\title{
Graceful remedies: understanding grace in the Catholic Church's treatment of clerical child sexual abuse
}

Article

Accepted Version

Gleeson, K. and Zanghellini, A. (2015) Graceful remedies: understanding grace in the Catholic Church's treatment of clerical child sexual abuse. Australian Feminist Law Journal, 41 (2). pp. 219-235. ISSN 1320-0968 doi:

https://doi.org/10.1080/13200968.2015.1077551 Available at https://centaur.reading.ac.uk/42077/

It is advisable to refer to the publisher's version if you intend to cite from the work. See Guidance on citing.

Published version at: http://dx.doi.org/10.1080/13200968.2015.1077551

To link to this article DOI: http://dx.doi.org/10.1080/13200968.2015.1077551

Publisher: Taylor and Francis

All outputs in CentAUR are protected by Intellectual Property Rights law, including copyright law. Copyright and IPR is retained by the creators or other copyright holders. Terms and conditions for use of this material are defined in the End User Agreement.

www.reading.ac.uk/centaur 
Central Archive at the University of Reading

Reading's research outputs online 


\title{
GRACEFUL REMEDIES: UNDERSTANDING GRACE IN THE
}

\author{
CATHOLIC CHURCH'S TREATMENT OF CLERICAL
}

\section{CHILD SEXUAL ABUSE}

\section{Kate Gleeson; Aleardo Zanghellini*}

\begin{abstract}
This article examines advocacy of Catholic restorative justice for clerical child sexual abuse from the standpoint of feminist criminological critiques of the use of restorative mediation in sexual offence cases. In particular, it questions the Catholic invocation of grace and forgiveness of survivors of abuse in light of critical feminist concerns about the exploitation of emotions in restorative practices, especially in regard to sexual and other gender-based offences. In the context of sexual abuse, the Catholic appeal to grace has the potential for turning into an extraordinary demand made of victims not only to rehabilitate offenders and the church in the eyes of the community, but also to work towards the spiritual absolution of the abuser. This unique feature of Catholic-oriented restorative justice raises important concerns in terms of feminist critiques of the risk of abuses of power within mediation, and is also incompatible with orthodox restorative justice theory, which, although it advocates a 'spiritual' response to crime, is concerned foremost with the rights, needs and experiences of victims.
\end{abstract}

\subsection{Introduction}

The international crisis of revelations of enduring and systemic abuse in Catholic (and other) institutions has led some scholars, practitioners and churches to advocate restorative justice as a remedy for historical child sexual abuse perpetrated by clergy and other church personnel. Advocacy of restorative justice in this context is based on the unique harms of clerical child sexual abuse, which devastate relationships: spiritual, interpersonal and communal. Arguments for the healing of such relationships via restorative justice are grounded in the characterisation of the practice as an inherently Christian enterprise premised

\footnotetext{
* Kate Gleeson is Senior Lecturer at Macquarie Law School. kate.gleeson@mq.edu.au. Aleardo Zanghellini is Professor of Law and Social Theory at the University of Reading, UK. a.zanghellini@reading.ac.uk. Sincere thanks to the anonymous reviewers of this journal for insightful advice.
} 
on 'grace', which may at first appear consistent with generalist restorative justice scholarship and processes emphasising the healing potential of forgiveness for the victims, or survivors, of abuse. 'Grace', however, has a unique meaning in Catholic thought and is arguably distinct from secular understandings of the concept. In this article we provide a theoretical discussion of the Catholic doctrine of grace to explain what it would mean to apply this doctrine in the context of restorative justice in cases of historical clerical child sexual abuse. We do so in light of critical feminist criminological concerns about the exploitation of emotions such as forgiveness in restorative practices, especially in regard to sexual and other gender-based offences.

'Grace' in the Catholic context is not simply an invocation of goodwill; the forgiveness that Catholic 'grace' suggests is not simply an appeal to victims to reconcile relationships with perpetrators. Rather, an analysis of the doctrine of grace in regard to crime suggests that grace is concerned with the church's performance of good offices on behalf of the perpetrator to rehabilitate him in the eyes of God and to induce, in support of this goal, the forgiveness of those whose bodily and psychosexual boundaries he has transgressed. As we will show, the grace of God is, first and foremost, what the perpetrator of the abuse has lost in committing abuse. Grace is also, however, what can be wished upon him, as it were, by the victim. In Catholic thought, the victim of a crime has the power to invoke 'actual graces' (Godly gifts) that will help the perpetrator of that crime recover the full grace of God, which will in turn cleanse him of sin and save his soul.

\footnotetext{
${ }^{1}$ We note here that we are sensitive to the need for victims of abuse to reclaim the loss of subjectivity, control and empowerment denoted by the term 'victim' through the alternative use of the word 'survivor'; yet we must also acknowledge 'victim' and 'offender' as legal entities. This paper thus refers to people who have experienced abuse as 'victims' when we wish emphasise their status as objects of violation by perpetrators, and as 'survivors' when we wish to place the emphasis instead on their subjective capacity for agency beyond the victim/offender dichotomy, or to indicate life lived beyond the initial instance/s of abuse.
} 
Thus, in the context of restorative justice and sexual abuse, we suggest that a Catholic appeal to grace has the potential for turning into an extraordinary demand made of victims not only to rehabilitate offenders and the church in the eyes of the community, but also to work towards the spiritual absolution of the abuser. This feature of Catholic doctrine raises important concerns in terms of feminist critiques of the risk of gendered abuses of power within mediation, and is also incompatible with orthodox restorative justice theory, which, although it advocates a 'spiritual' response to crime, is concerned foremost with the rights, needs and experiences of victims.

We begin by briefly outlining the conventional understanding of restorative justice, which makes redress of harm to victims its central goal, and we discuss feminist concerns that restorative justice may fail to deliver on this goal in the context of sexual crime, especially in its focus on forgiveness and the reconciliation of relationships. We then clarify the special nature of Christian advocacy for restorative justice, which is centred on the concepts of forgiveness and grace, and demonstrate the recent trend in advocating and implementing church-run restorative justice schemes for child sexual abuse in this context. We examine the goals of these schemes as stated by their advocates and explain how the Catholic doctrine of grace requires the pre-eminence of a goal not always explicitly emphasised, namely, the rehabilitation - not only societal, but also spiritual - of the offender. Lastly, we show how this logic of Catholic grace all but requires the cooperation of the survivor of the abuse in this rehabilitation, through the act of forgiveness, and how this example gives particular force to feminist concerns about the emotionally exploitative potential of restorative justice in cases of sexual crime. We conclude by drawing attention to the epistemological discontinuities between calls for restorative justice centred on Catholic grace and orthodox (victim-centred) restorative justice, and we warn of the perils of theorists and practitioners uncritically appropriating theological terminology, especially in the context of very grave offences such as child sexual abuse. 


\subsection{Restorative Justice and Feminist Critiques}

Restorative justice is a form of alternative dispute resolution offered as an adjunct to criminal justice, which aims to bring together all stakeholders affected by harm in a process distinct from traditional corrective justice, in which addressing the "harm done to the victim takes precedence'. ${ }^{2}$ Crime is viewed as a violation of human relationships, and the restorative process focuses on the restoration of those relationships, offering the 'reunion of the two individuals and of the individual with the community' ${ }^{3}$ as a way of 'healing the hurts of injustice and transforming the conditions that allowed injustice to flourish'. ${ }^{4}$ Typically, restorative justice is promoted in contrast to adversarial criminal justice, which is not victimcentred and 'effectively discourages truth telling and inadvertently discourages offenders from acknowledging responsibility for their crime'. 5

Support for restorative justice in the context of sexual crime tends to reflect disenchantment with the criminal justice system, whereby despite 30 years of 'significant change' to responses to sexual violence, conviction rates have fallen in Australia, Canada, England, Wales and elsewhere. ${ }^{6}$ For example, a 2014 Irish study (hereafter, the Irish Study)

\footnotetext{
${ }^{2}$ Umbreit Mark and Armour Marilyn Peterson Restorative Justice Dialogue: An Essential Guide for Research and Practice Springer Publishing Company New York 2010 p 7.

${ }^{3}$ Gavrielides Theo 'Clergy Child Sexual Abuse and the Restorative Justice Dialogue' (2012) 55 Journal of Church and State 617 p 62.

${ }^{4}$ Braithwaite John Restorative Justice and Responsive Regulation Oxford University Press New York 2002 p 564.

${ }^{5}$ Keenan Marie Sexual Trauma and Abuse: Restorative and Transformative Possibilities? A Collaborative Study on the potential of Restorative Justice in Sexual Crime in Ireland University College Dublin School of Applied Social Science Dublin 2014 p 21.

${ }^{6}$ Daly Kathleen 'Conventional and Innovative Justice Responses to Sexual Violence' (2011) 12 ACSSA Issues 1 p p 1.
} 
based on interviews with sex offenders, victims and other stakeholders concluded that due to the very high attrition rate for the criminal treatment of sexual offences, restorative justice programs should be trialled in Ireland. ${ }^{7}$ Legal theorists such as Carol Smart and Nicola Lacey maintain that the failures of conventional criminal justice are not procedural, but intrinsic to the criminal law, which 'disqualifies' the harm of sexual violence. ${ }^{8}$ In this context, Hudson writes of the discursive power of restorative justice to challenge stereotypical understandings of sexual victimisation, blame and responsibility. ${ }^{9}$ Similarly, the authors of the Irish Study describe victims as desiring a 'rebalancing of the power dynamic' of sexual offences, which restorative justice may provide. ${ }^{10}$

While over the past two decades, restorative justice has been promoted as an answer, and in some cases 'the answer' ${ }^{11}$ to the failings of criminal justice, its use in cases of sexual violence and other gender-based harms remains the topic of 'vigorous' debate among criminologists and practitioners. ${ }^{12}$ Feminist critiques of restorative practices have mostly been made theoretically, in the context of adult survivors of recently committed offences. There exists only a handful of studies appraising restorative justice programs delivered in the context of sexually violent offences, such as victim-offender mediation for juvenile offenders

\footnotetext{
${ }^{7}$ Keenan Sexual Trauma and Abuse.

${ }^{8}$ Lacey in Daly 'Conventional and Innovative Justice Responses' p 3.

${ }^{9}$ As above at $\mathrm{p} 24$.

${ }^{10}$ Keenan Sexual Trauma and Abuse p 173.

${ }^{11}$ Stubbs Julie ‘Restorative Justice, Domestic Violence and Family Violence' (2004) Domestic Violence and Family Violence Clearinghouse, Issues Paper 9 p 1 emphasis in original.

${ }^{12}$ Keenan Marie and Joyce Niamh Restorative Justice and Sexual Violence: Ireland Joins the international Debate University College Dublin School of Applied Social Science Dublin 2013 p 8.
} 
and prison inmates. ${ }^{13}$ Restorative justice in the context of historical, institutional child sexual abuse is particularly under-studied. A 2011 Scottish pilot study of adult survivors of childhood abuse in care determined that restorative justice 'can be a positive remedy for some survivors' as it may help them 'deal with' the harm they suffered, and offenders to 'accept responsibility for this harm'. ${ }^{14}$ However, New Zealand research found that survivors of historical child sexual abuse are reluctant to participate in restorative justice and that any targeted programs would need to accommodate their recovery processes and difficulties associated with disclosing abuse to family and friends. ${ }^{15}$ Crucially, there exists no comparative analysis of historical sexual offences finalised in court and by restorative conferences. $^{16}$

Some authors and practitioners warn that all forms of alternative dispute resolution risk 'domesticating stories of violence so they become stories of conflict' ${ }^{17}$ by reframing victims' rights as needs and depoliticising gender-based harms by embodying the 'qualities of the private' in mediation. ${ }^{18}$ In particular, Stubbs disputes the ability of restorative justice to remedy gender-based offences, which are not incident-based but repeated, often over many years, and are concerned with power and control. ${ }^{19}$ Theorising crime as primarily a conflict

\footnotetext{
${ }^{13}$ As above at $\mathrm{p}$ 15; see also Daly Kathleen 'Restorative Justice and Sexual Assault: An Archival Study of Court and Conference Cases' (2006) 46 British Journal of Criminology 334.

${ }^{14}$ Survivor Scotland 2011 http://www.survivorscotland.org.uk/confidential-forum/time-to-beheard/restorative-justice-toolkit/.

${ }^{15}$ Jülich Shirley 'Views of Justice among Survivors of Historical Child Sexual Abuse: Implications for Restorative Justice in New Zealand' (2006) 10 Theoretical Criminology 125 p 136.

${ }^{16}$ Daly Kathleen 'Conventional and Innovative Justice p 23.

${ }^{17}$ Cobb and Coker in Braithwaite Restorative Justice p 252.

${ }^{18}$ Braithwaite Restorative Justice p 252.

${ }^{19}$ Stubbs 'Restorative Justice' p 6.
} 
between individuals fails to engage with questions of structural disadvantage and with systemic raced, classed and gendered patterns of crime. ${ }^{20}$

Of crucial concern to Stubbs is the role of emotions connected to remorse, apology and forgiveness in restorative practices, which Braithwaite identifies as the 'central focus' of the process: 'the objective is to get all the dimensions of how people feel into the circle so everyone in the circle can ask themselves if they can make any contribution to resolving those feelings. ${ }^{21}$ To succeed at providing a sense of justice, restorative justice requires offender remorse. However, gendered and sexual abuses tend to be characterised by power and control, the effects of which the offender is unlikely to appreciate. ${ }^{22}$ Cossins suggests it is possible for offenders to apologise without remorse and for victims to feel distress during restorative processes, ${ }^{23}$ as questions of forgiveness and grace loom large in their experiences. Although Braithwaite cautions it is 'cruel and wrong' to necessarily expect forgiveness, ${ }^{24}$ restorative justice theory and practice does value forgiveness as healing and empowering for victims. ${ }^{25}$ Hence, Stubbs warns of ethical challenges for mediators who may communicate expectations of apology and forgiveness and exploit gendered emotions in the pursuit of outcomes valued in restorative justice. Restorative justice advocates rarely engage adequately

\footnotetext{
${ }^{20}$ As above.

${ }^{21}$ Braithwaite Restorative Justice p 252.

${ }^{22}$ Stubbs ‘Restorative Justice’ p 171.

${ }^{23}$ Cossins Anne 'Restorative Justice and Child Sex Offences: The Theory and the Practice' (2008) 48 British Journal of Criminology 359 p 362.

${ }^{24}$ Braithwaite Restorative Justice pp 570-71.

${ }^{25}$ Zehr Howard Changing Lenses. A New Focus for Crime and Justice Herald Press Scottdale 2005 pp 49-52; Umbreit and Armour Restorative Justice Dialogue pp 74-5.
} 
with questions of 'how gender, and other social relations, might be related to the construction of meaning within, and to the emotional dynamics of, restorative processes'. ${ }^{26}$

\subsection{The Christian Approach to Restorative Justice}

Feminist attention to the use of emotions in mediation is, ironically, mirrored in Christian advocacy of restorative justice, which promotes forgiveness and grace as the practice's most compelling and therapeutic features offering a form of transcendence for both victims and offenders. While many theorists associate the movement's key concepts with traditional indigenous cultures, ${ }^{27}$ Christian advocates, including judges and other legal representatives, instead promote restorative practices as offering redemption of offenders and the justice system as a whole, in terms of Judaeo-Christian biblical teachings. Some of the strongest advocacy of restorative justice emanates from Christians inspired by founding theorist Mennonite Christian Howard Zehr, who stresses the centrality of forgiveness to restorative approaches, as something 'that must come in its own time with God's help' ${ }^{28}$ Christians characterise restorative justice as challenging the legal community to transform its focus from punishing offenders to 'inspiring grace in victims and offenders by showing compassion'. ${ }^{29}$ In this argument, orthodox justice represents a failure of morality, spirituality and legal procedure. Crucially, justice hinges on the 'hard' emotional work of victims to forgive:

\footnotetext{
${ }^{26}$ Stubbs Julie 'Beyond Apology? Domestic Violence and Critical Questions for Restorative Justice’ (2007) 7 Criminology \& Criminal Justice 169 p 172.

${ }^{27}$ Armour and Umbreit 'Victim Forgiveness in Restorative Justice Dialogue' (2006) 1 Victims and Offenders: An International Journal of Evidence-Based Research, Policy and Practice 123 p 124.

${ }^{28}$ Zehr Changing Lenses p 46.

${ }^{29}$ Grimes Diana 'Practice What You Preach: How Restorative Justice Could Solve the Judicial Problems in Clergy Sexual Abuse Cases' (2006) 63 Washington and Lee Law Review 1693 p 1703.
} 
While punitive justice does little to actually mend wrong, restorative justice in contrast is all about making things right, about changing negative dynamics and helping people to overcome hurt. That's what grace is all about: It does not ignore problems, but in fact addresses them on a much deeper level than punitive justice does. So while grace may be in conflict with a strictly punitive understanding of justice, it is not in conflict with restorative justice. In fact, grace is all about restorative justice. ... Grace is indeed hard, but even taking a few small faltering steps in its direction can open the doors for healing to start and violence to stop. That's why grace is not an ideal luxury, but quite literally a life and death necessity. Grace is the very means by which true justice comes about. ${ }^{30}$

Even secular restorative justice theory sometimes emphasises the Christian roots and spiritual dimensions of the practices. Braithwaite cites St Paul that 'where sin abounded, grace did much more abound' and describes crime as an 'opportunity to prevent greater evils, to confront crime with a grace that transforms human lives to paths of love and giving, ${ }^{31}$ Grace he promotes as providing victims the 'spiritual restoration' required for healing. ${ }^{32}$ However orthodox theorists such as Braithwaite tend not to explain what they understand or mean by theological concepts such as 'grace', or the essential implications of this 'spiritual' worldview for victims and offenders participating in mediation. Even Zehr appears to collapse the categories of 'forgiveness' and 'grace' as one and the same, despite the distinct

\footnotetext{
${ }^{30}$ Flood Derek 'Restorative Justice and the Economy of Grace' Huffington Post 20 October 2011

http://www.huffingtonpost.com/derek-flood/restorative-justice-and-t_b_1016850.html.

${ }^{31}$ Braithwaite Restorative Justice $\mathrm{p} 3$.

${ }^{32}$ As above at $\mathrm{p} 46$.
} 
theological meaning of the latter. ${ }^{33}$ The uncritical promotion of Christian terminology in restorative justice scholarship has meant that increasingly such arguments have come to be applied to cases of clerical child sexual abuse, and have acquired distinctive connotations in the Catholic context, with its characteristic understanding of grace, mortal sin and salvation. The implications of this may not be appreciated by theorists and practitioners who unwittingly grant Catholic Church-run restorative justice programs authority.

\subsection{Catholic Restorative Justice and Child Sexual Abuse}

Following the 1990s' North American 'litigation explosion', which had been forewarned by the US Catholic hierarchy as 'the most serious crisis that we in the church have faced in centuries', numerous dioceses in Canada and the US filed for bankruptcy protections and sought means by which to settle sex abuse complaints out of court. ${ }^{34}$ This included the development and delivery of in-house restorative justice programs facilitating mediation with adult survivors of church-based childhood abuses. Advocates of these programs link contemporary restorative justice values to those upheld by the church 'throughout history', such as by way of the Catholic confessional, which developed as a 'restorative approach to encourage personal responsibility and reconciliation with God' ${ }^{35}$ It is the teaching of the church that punishment for a crime, 'in addition to defending public order and protecting people's safety, has a medicinal purpose: As far as possible, it must contribute to the correction of the guilty party' ${ }^{36}$ Restorative justice is therefore promoted as a means compatible with the Catholic approach to crime for 'repairing harm by giving voice to the

\footnotetext{
${ }^{33}$ Zehr Changing Lenses p 51.

${ }^{34}$ Jenkins Philip Pedophiles and Priests: Anatomy of a Contemporary Crisis Oxford University Press Oxford and New York 2001 p 37.

${ }^{35}$ Grimes 'Practice What You Preach’ p 1703.

${ }^{36}$ Catechism of the Catholic Church no 2266.
} 
victims, restoring the community and rehabilitating offenders through responsibility and reconciliation', ${ }^{37}$ with 'equal weight' given to the interests of the victims, the church and perpetrators, and the community. ${ }^{38}$

In the context of clerical child sexual abuse, restorative justice is promoted as being in the best interests of both victims and the church. Mediation is promoted as best for victims, with arguments that orthodox justice fails to address their particular 'esoteric pathos', ${ }^{39}$ while restorative justice is promoted as best for the church in terms of its being 'rooted in theology and the Christian themes of forgiveness and reconciliation [which] should make it particularly attractive to a Church craving reunion with its followers and a higher moral road not offered by the traditional justice system ${ }^{40}$

Justified as such, restorative justice programs have come to be offered as a form of salvation for survivors and offenders in the US, New Zealand, Australia, the Netherlands and elsewhere. ${ }^{41}$ This is despite the lack of significant robust research determining the suitability and efficacy of restorative justice for historical, institutional child sexual abuse noted above. Organisations such as the British Independent Academic Research Studies think tank have begun to document (and advocate for) existing programs. ${ }^{42}$ International data are generally incoherent, however, as programs tend to operate beyond the shadow of the law and are individual to the communities and organisations that host them: 'there is no central registry.

\footnotetext{
${ }^{37}$ Catholic Mobilizing Network 2015 http://catholicsmobilizing.org/8436/november-21-2014-conferencerestorative-justice-washington-d-c/. 
There is no one prototype. Information ... is scattered and empirical' ${ }^{43}$ It is not apparent to what extent various church-led processes abide by restorative justice standards or provide a sense of justice for survivors and offenders.

Although representatives of the Vatican have made public statements that sex offenders should remain accountable through ordinary criminal justice processes, and orthodox restorative justice theory mandates that mediation only ever be offered as an optional adjunct to criminal processes, some Catholic advocates such as Grimes steer perilously close to advocating the undermining of established restorative justice standards, and the rule of law, when they suggest that the best way to 'break the cycle' is for 'the church and the offending priests to meet with the victims and settle the problems outside of the judicial system'. ${ }^{44}$ Furthermore, significant evidence collated in government inquiries suggests, for example, that Australian Catholic Church-led processes fail to uphold general restorative justice standards aimed at protecting victims, and do not confront the specific feminist concerns about cases of sexual abuse, especially historical institutional child sexual abuse. $^{45}$

\subsection{Restoring Relationships: The Essence of Restorative Justice}

Orthodox restorative justice theory aims to harness forgiveness and 'grace' to restore relationships, where possible, between victim, offender and community. Hence Catholic advocates argue that restorative justice may perform the function of restoring four unique relationships central to religious child sexual abuse. First among these is the relationship of survivors to their faith. Clerical child sex offences share common attributes with other child sex offences: calculated, premeditated grooming activities to gain sexual access to a child,

\footnotetext{
${ }^{43}$ Beaty 'Faith-Based Organizations ‘ p 29.

${ }^{44}$ Grimes ‘Practice What You Preach’ p 1695.

${ }^{45}$ Gleeson 'The Money Problem'.
} 
with risks and benefits weighed up by perpetrators; repeated abuse escalating in gravity of offences; and significant time-lags in reporting, if ever, ${ }^{46}$ with the criminal justice system experienced as 'extremely traumatic by victims and their families' ${ }^{47}$ Most, if not all, sexual abuse provokes 'potent and debilitating self-blame' among victims. ${ }^{48}$ However, it is argued, along with the violation of a sacrosanct relationship that 'once embodied ultimate trust', ${ }^{49}$ abuse by clergy constitutes the extra abusive dimension of the violation of an individual's basic human right to faith and identity, which may be experienced by Catholic religious victims as a 'sacrilege that offends against a sacramental worldview' that is central to Catholicism. $^{50}$

Abuse by clergy results in significant trauma and distress related to 'theological belief, crises of faith, and fears about one's mortality'. ${ }^{51}$ These are outcomes one Christian commentator described in terms of the 'murder of a person's soul', 52 which orthodox justice is not equipped to address. The spiritual nature of abuse brings with it particular individual harms akin to post-traumatic stress disorder with potentially lifelong effects and may also act as a significant deterrent for acknowledging and/or reporting abuse, ${ }^{53}$ with concomitant harms that extend to the religious community, including the victim's family. Catholic

\footnotetext{
${ }^{46}$ Cossins 'Restorative Justice' p 365.

${ }^{47}$ Keenan Sexual Trauma and Abuse p 30.

${ }^{48}$ As above at $\mathrm{p} 20$.

${ }^{49}$ Gavrielides and Coker 'Restoring Faith' p 346.

${ }^{50}$ Guido Joseph J 'A Unique Betrayal: Clergy Sexual Abuse in the Context of the Catholic Religious Tradition' (2008) 17 Journal of Child Sexual Abuse 255 p 260.

${ }^{51}$ Gavrielides ‘Clergy Child Sexual Abuse’ p 620.

${ }^{52}$ As above at p 620.

${ }^{53}$ As above.
} 
restorative justice advocates argue that healing must attend to the religious challenges implied by the abuse, ideally through restorative mediation.

A second aim for Catholic advocates concerns the restoration of the survivor's relationship with, if not the individual perpetrator, then the church as a whole. Complicity of the institution and religious hierarchy has frequently compounded effects of abuse for which the church has been found morally and legally liable in numerous jurisdictions. While restorative justice has typically been theorised and implemented to address relationships between individuals, some authors optimistically advocate for its healing capacities to extend to the relationship between the individual and the institution.

A third aim concerns that of restoring the relationship of the church with the religious community to allow, ideally, a diocese 'to stand proud before parishioners and others' ${ }^{54}$ Some Catholic respondents to the Irish Study noted the inability of the criminal justice system to perform this function, and identified non-complicit members of the church, as well as congregations, as 'secondary victims' of perpetrators' abusive behaviours. Restorative justice was viewed as offering great potential for internal and external church reconciliation, ${ }^{55}$ even though the process focuses on the experiences of individual victims.

Finally, is the aim of restoring the perpetrator's relationship with the church, which we argue is the most pressing concern for considerations of the role of grace and emotion in restorative practices. Some Catholic religious leaders responding to the Irish Study noted that clerical offenders feel 'abandoned' by the church as they progress through criminal or civil proceedings. ${ }^{56}$ The respondents identified hypocrisy in this abandonment - 'You can't preach forgiveness and not give forgiveness' - and viewed restorative justice as potentially

\footnotetext{
${ }^{54}$ Gavrielides 'Clergy Child Sexual Abuse’ p 627.

${ }^{55}$ Keenan Sexual Trauma and Abuse pp 290-1.

${ }^{56}$ As above.
} 
'humanising' for offenders and allowing for reconciliation with their faith and the church. ${ }^{57}$ An analysis of the Catholic doctrine of grace explains why these respondents may have viewed Catholic restorative justice as capable of restoring perpetrators not only to the Church, but to God Himself. We turn to this analysis in the next section, arguing that in most cases the logic of Catholic grace all but requires that Catholic approaches to restorative justice invoking grace make the offender's salvation their primary object of concern.

\subsection{Sanctifying Grace and the Perpetrator of Abuse}

In Catholic thought, 'grace' is a term of art with several layers of meaning. To appreciate the implications of making grace central to the practice of restorative justice one needs to attend to those layers. Orthodox restorative justice theory, with its loose talk of 'grace', 'forgiveness' and 'spirituality', has the effect of uncritically ratifying Catholic calls for restorative justice without attending to these complexities, or even to the particular Catholic approach to crime. As we argue in this section, the logic of the Catholic doctrine of grace would require, in most cases, the pre-eminence of the aim of restoring the offender to the grace of God - a result which sits uncomfortably with orthodox theory's emphasis on the need that restorative programs remain victim-centred.

The Catholic doctrine of grace sets apart Catholicism from various forms of Protestantism. Rooted in St Paul's 1st century CE writings, it was fully articulated over time, primarily in the writings of St Augustine (354-430) and in the context of the Council of Trent (1545-1563), in response to heretic and reformist claims about original sin and free will.

In Catholic thought, grace is a particular kind of spiritual gift freely bestowed by God on human beings, which can be divided into sanctifying (or habitual) grace and actual grace.

\footnotetext{
${ }^{57}$ As above.
} 
Sanctifying grace is the 'supreme grace' ${ }^{58}$ Only those who die in a state of sanctifying grace have a claim to heaven after death. Sanctifying grace changes the nature of those who enjoy it, regenerating them into new life, ${ }^{59}$ and making them 'partakers of the Divine nature', 60 God's friends ${ }^{61}$ and God's sons. ${ }^{62}$ The act of establishing this communion with God is called 'justification' and those who are thus 'justified' by grace are called 'the just'. ${ }^{63}$ The 'life of grace' that the just enjoy shades into the 'life of glory' characteristic of their afterlife. ${ }^{64}$

Adam and Eve, prior to revolting against God's law, were in a state of 'original justice': ${ }^{65}$ they enjoyed, that is, not only sanctifying grace but also 'integrity' - namely 'the perfect subjection of the appetites to reason and of the body to the soul' ${ }^{66}$ Upon sinning, they lost both sanctifying grace and integrity, for themselves as well as their offspring. ${ }^{67}$ God saw

\footnotetext{
58 Joyce George Hayward The Catholic Doctrine of Grace Burns Oates and Washbourne London 1920 p 22.

${ }^{59}$ As above at p 12; Pohle Joseph and Preuss Arthur Grace, Actual and Habitual: A Dogmatic Treatise Herder St Louis 1915 p 272, pp 312-13, p 334.

${ }^{60}$ Joyce The Catholic Doctrine of Grace p 22. See also pp 35-9; and Pohle and Preuss Grace, Actual and Habitual p 340.

${ }^{61}$ Pohle and Preuss Grace, Actual and Habitual pp 351-5.

62 Joyce The Catholic Doctrine of Grace pp 2-3. See also Pohle and Preuss Grace, Actual and Habitual pp 35662.

63 Joyce The Catholic Doctrine of Grace pp 43-5.

${ }^{64}$ As above at $\mathrm{p} 34$.

${ }^{65}$ As above at pp $54-5$.

${ }^{66}$ As above at $\mathrm{p} 53$.

${ }^{67}$ As above at p 52; Augustin Aurelius 'A Treatise on the Grace of Christ, and on Original Sin' in Philip Schaff (ed) A Select Library of the Nicene and Post-Nicene Fathers of the Christian Church, Vol 5 (St Augustin's Anti-
} Pelagian Writings) The Christian Literature Company New York 1887 p 217 at p 249. 
it fit to make the gift of integrity irrecoverable. ${ }^{68}$ On the other hand, sanctifying grace can be restored through baptism, which cleanses humans of original sin. ${ }^{69}$

Just as sanctifying grace displaces original sin at the moment of baptism, deliberately committing mortal sin expels sanctifying grace from the $\operatorname{sinner}^{70}$ (serious $\sin$ is called 'mortal' precisely because it extinguishes the life of grace in the soul). Complete sinlessness is unavoidable ${ }^{71}$ except by God's special privilege; ${ }^{72}$ and venial sin (that is, sin that is either not serious or not fully deliberate $)^{73}$ is compatible with the state of grace and does not even diminish it. ${ }^{74}$ Mortal sin and grace, however, are radically incompatible. Mortal sin substitutes enmity with God for the Divine sonship and fellowship enjoyed by the just. ${ }^{75}$

The infusion of sanctifying grace into the soul through baptism also confers on the baptised the 'theological virtues': faith in God, the hope or desire to attain or possess Him and charity or love of God. ${ }^{76}$ These virtues are called 'theological' because they have God as their direct object. ${ }^{77}$ Baptism also bestows, according to most theologians, the so-called 'infused virtues': prudence, justice, fortitude, temperance and others. ${ }^{78}$

${ }^{68}$ Joyce The Catholic Doctrine of Grace p 56; Augustin Aurelius 'A Treatise on Nature and Grace' in Philip Schaff (ed) A Select Library of the Nicene and Post-Nicene Fathers of the Christian Church, Vol 5 (St Augustin's AntiPelagian Writings) The Christian Literature Company New York 1887 p 115 at p 150.

${ }^{69}$ Pohle and Preuss Grace, Actual and Habitual pp 302-3, p 306.

${ }^{70}$ As above at p 392.

71 Joyce The Catholic Doctrine of Grace p 155.

72 Pohle and Preuss Grace, Actual and Habitual p 114.

${ }^{73}$ As above at $\mathrm{p} 115$.

${ }^{74}$ As above at $\mathrm{p} 388$

${ }^{75}$ Joyce The Catholic Doctrine of Grace pp 39-42, 202-3.

${ }^{76}$ As above at p 76; Pohle and Preuss Grace, Actual and Habitual p 339, 363.

77 Joyce The Catholic Doctrine of Grace pp 88-9.

${ }^{78}$ As above at pp 89-90; Pohle and Preuss Grace, Actual and Habitual p 363. 
In committing mortal sin, the sinner deliberately rejects the love of God. Thus, mortal sin involves the loss of charity as well as sanctifying grace. Faith and hope, however, remain with sinners ${ }^{79}$ (only by committing the specific sin of unbelief or infidelity can faith be lost), ${ }^{80}$ enabling them to return to God if they are so disposed. ${ }^{81}$ In particular, sinners are restored to both grace and charity if they go through the sacrament of penance (confession), feeling 'genuine sorrow', intending to make amends, and casting 'out of [their] soul whatever is incompatible with the love of God' ${ }^{82}$

Sins of the sexual variety feature prominently among those that expel sanctifying grace from the soul, preventing humans from attaining celestial beatitude after death. ${ }^{83}$ Child sexual abuse is no exception: in his 'Letter to the Catholics of Ireland' of 2000, Pope Benedict XVI, in urging offending priests to repent and atone for their actions, reminded them that 'Christ's redeeming sacrifice has the power to forgive even the gravest of sins, and to bring forth good from even the most terrible evil. ${ }^{, 84}$ This terminology demonstrates that the spiritual condition of the perpetrator of sexual abuse - and in particular the imperative of restoring his justification - has a special urgency from the perspective of the church. Any church-run restorative justice processes emphasising grace, we argue, must primarily be concerned with the rehabilitation of the offender in the eyes of God: they are 'restorative' primarily in the sense of restoring the offender to the state of sanctifying grace.

In centring grace, Catholic justice entails that concern for the survivor will in many (but not all) cases be of secondary importance. Unlike offenders, victims have not, by virtue

\footnotetext{
${ }^{79}$ Pohle and Preuss Grace, Actual and Habitual p 174, 390; Joyce The Catholic Doctrine of Grace pp 203-4.

${ }^{80}$ Pohle and Preuss Grace, Actual and Habitual pp 395-6.

${ }^{81}$ Joyce The Catholic Doctrine of Grace p 206.

${ }^{82}$ As above at $\mathrm{p} 88$.

${ }^{83}$ Pohle and Preuss Grace, Actual and Habitual p 394.

${ }^{84}$ Pope Benedict XVI in Robertson Geoffrey The Case of the Pope Penguin 2010 p 38-9 (emphasis added).
} 
of the sin of abuse, lost justification. To be sure, we cannot be certain of whether or not they are justified; this, however, is simply the uncertainty that attends everyone's justification, for we can never be altogether sure to have met all the pre-requisites for receiving sanctifying grace. ${ }^{85}$ The victims' salvation is as important as everyone's, but the church has no reason to believe that it is in jeopardy more than anyone else's. In the case of the abuser, on the contrary, it has compelling reasons for believing just that: assuming the perpetrator had been justified prior to the abuse, he necessarily lost justification upon committing abuse - a mortal sin. Spiritually speaking, then, the offender needs more assistance than the victim.

This does not mean that, when Catholic advocates of restorative justice cite restoring faith to the survivor as the primary goal of the process, they are being dishonest. In those cases where victims have lost faith as a result of the abuse, the logic of grace does require that the church's concern for survivors be of overriding importance. This is because theological faith is "the beginning, the foundation, and the root of all justification", ${ }^{86}$ While perpetrators have lost justification upon committing the abuse, they have not thereby foregone the foundation of justification (faith), as this is only lost through the specific sin of unbelief. Victims who have lapsed into unbelief, on the other hand, have lost that very foundation: thus, their prospects of salvation are in even greater jeopardy than those of their abusers. Concern for such victims - the logic of grace demands - will necessarily be the foremost priority. It is important to stress, however, that it is only in the subset of sexual abuse cases involving victims who have lost faith that the logic of grace would require restorative justice to be victim-centred in this way. Furthermore, considering the sinful nature of unbelief, there is a real risk that an unbelieving survivor would psychologically experience as a form of victim-blaming any church-run processes aimed at assisting their conversion.

\footnotetext{
${ }^{85}$ Pohle and Preuss Grace, Actual and Habitual p 380.

${ }^{86}$ Cited in Pohle and Preuss Grace, Actual and Habitual p 182.
} 


\subsection{Actual Grace and the Perpetrator of Abuse}

The idea of sanctifying grace does not exhaust the Catholic doctrine of grace. If the concept of sanctifying grace explains why Catholic restorative justice needs to take the spiritual wellbeing of perpetrators as an especially serious concern, the concept of actual grace helps us understand how both perpetrators and survivors are positioned vis-à-vis that concern, as well as the demands made of them.

Actual graces are spiritual gifts from God - temporary 'motions' nondeterministically ${ }^{87}$ 'impelling the soul to this or that act ${ }^{88}$ by way of illuminating the mind and strengthening of the will. ${ }^{89}$ They are experienced as 'transient impulses' of the soul ${ }^{90}$ and are necessary in order to enable humans 'to perform salutary acts' ${ }^{91}$ '[S]alutary acts are those directed to the attainment of sanctifying grace'. ${ }^{92}$ Thus, actual graces are gifts conducive and necessary to the acquisition, maintenance and restoration of sanctifying grace. ${ }^{93}$ For example, in order for mentally competent adults to receive baptism, they need to possess certain internal states (faith in God, sorrow for past sins, etc.) that make them suitable recipients of

\footnotetext{
${ }^{87}$ Pohle and Preuss Grace, Actual and Habitual p 32; Joyce The Catholic Doctrine of Grace p 129.

${ }^{88}$ Joyce The Catholic Doctrine of Grace p 146.

${ }^{89}$ Pohle and Preuss Grace, Actual and Habitual pp 19-26; see also Augustin 'A Treatise on the Grace of Christ' pp 218-23, p 226.

${ }^{90}$ Pohle and Preuss Grace, Actual and Habitual p 12.

${ }^{91}$ As above at pp 1, 110.

${ }^{92}$ As above at $\mathrm{p} 82$.

${ }^{93}$ As above at pp 14-15, p 271.
} 
sanctifying grace. ${ }^{94}$ These internal states are themselves supernatural gifts of God - instances of 'actual grace' preparing their souls for the further gift of sanctifying grace. ${ }^{95}$

Maintaining sanctifying grace ('perseverance in grace') ${ }^{96}$ by avoiding mortal sin on anything more than a temporary basis similarly requires the assistance of actual grace. ${ }^{97}$ The main reason why humans need these actual graces 'over and above the ... endowment of [theological and infused] virtues, ${ }^{98}$ granted together with sanctifying grace is that, as we have seen, baptism does not also restore 'integrity'. As a result, humans in the state of justification remain besieged by temptations and ready to yield to 'concupiscence'. ${ }^{99}$ Actual grace temporarily heals this 'weakness of the will' resulting from original sin, ${ }^{100}$ enabling humans to fend off temptations to commit mortal sin. ${ }^{101}$ Thus, the actual grace consisting in the fear of offending God may aid the infused virtue of temperance to keep the just from giving in to sensualism. ${ }^{102}$

When humans lose justification as a result of committing mortal sin they can regain it by repenting. ${ }^{103}$ Repentance is itself a gift from God - that is, an actual grace - as sinners 'deprived of sanctifying grace cannot by [their] natural powers take a single step towards'

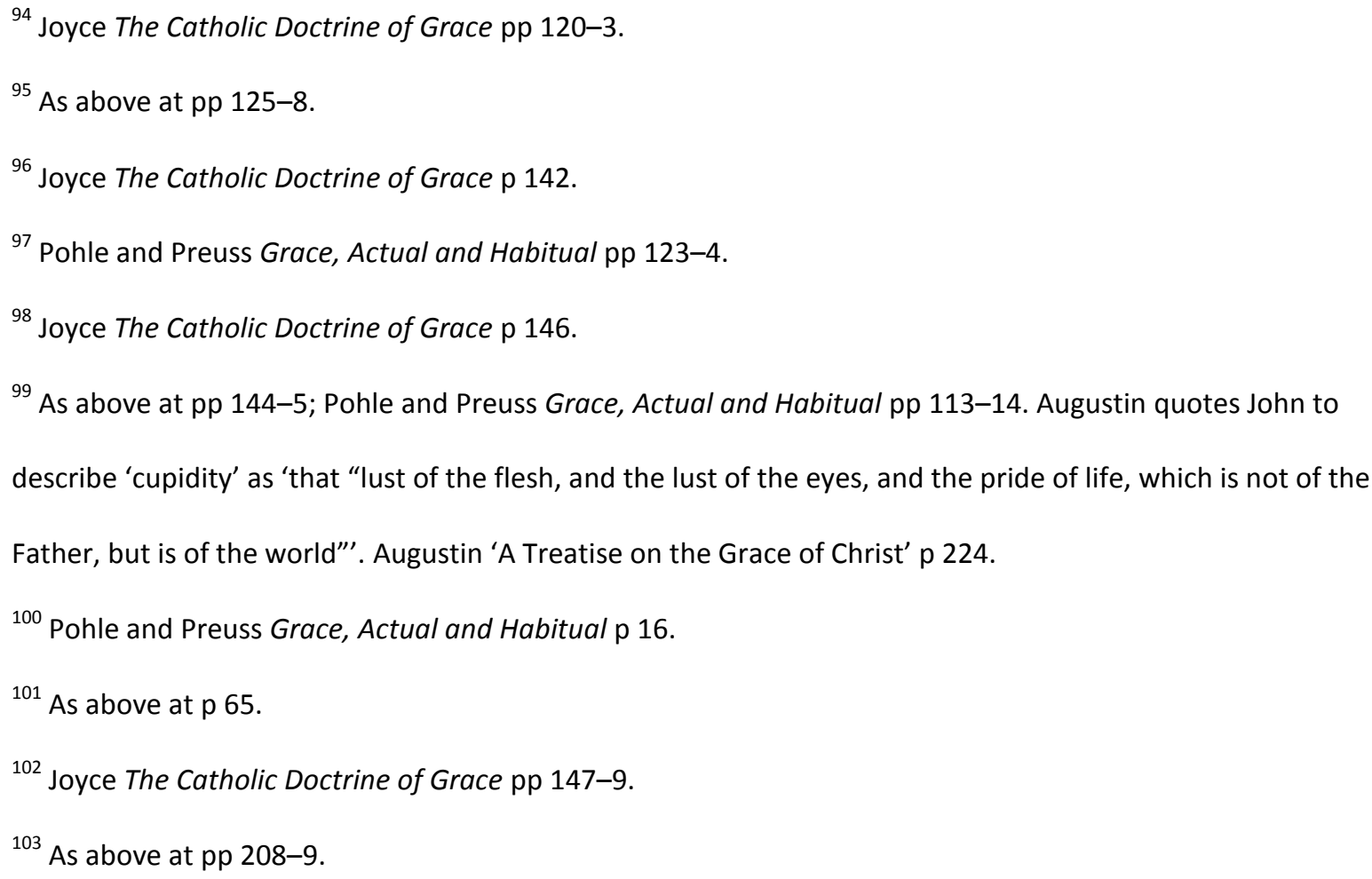


justification. ${ }^{104}$ If actual grace has the effect of infallibly moving the recipient to do the act for which the grace was granted (for example the act of repentance), the grace is called 'efficacious', otherwise it is merely a 'sufficient' grace. ${ }^{105}$ Because God's mercy is universal, he wants everyone's salvation: ${ }^{106}$ this means that He grants sufficient actual graces to all, even great sinners. ${ }^{107}$ This includes, of course, the perpetrators of sexual abuse. But a sufficient actual grace will not infallibly move the recipient to do the salutary act of repentance which will enable him to re-enter into the fold of sanctifying grace. The actual grace needs to be efficacious.

As the efficacy of actual grace is a function of the response made to it by the recipient's will, ${ }^{108}$ the church will be anxious, in clerical sexual abuse cases, to create the conditions conducive to the perpetrator's will appropriately responding to actual grace. The doctrine of justification insists that no-one can know 'with certainty of faith whether [they are] justified or not'. ${ }^{109}$ If it is always open to question whether anyone is in the state of sanctifying grace, the concern will logically be heightened in respect of anyone who is known to have committed mortal sin - particularly if, as in the case of perpetrators of sexual

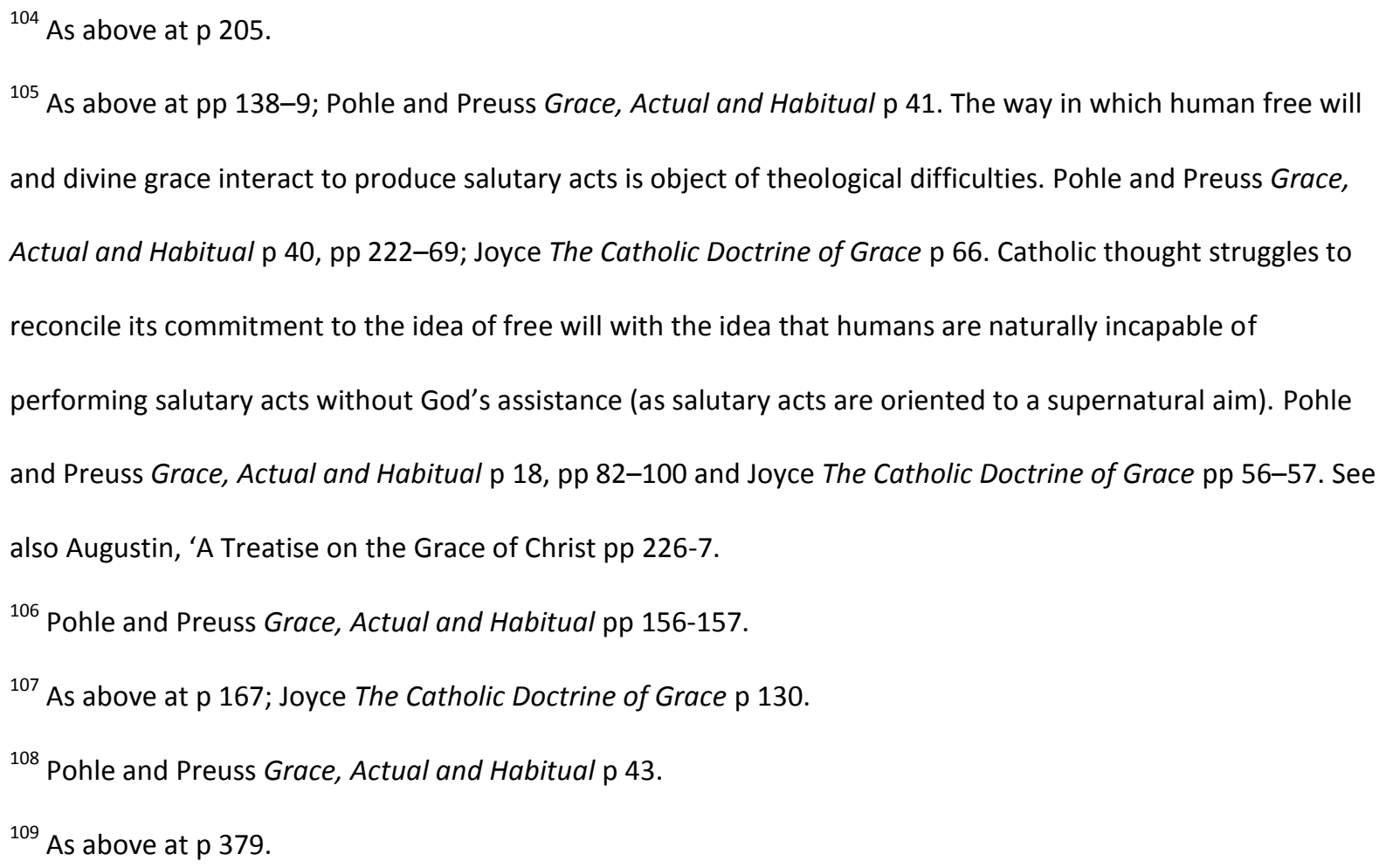


abuse, they have been repeat offenders over the course of many years. While it cannot be ruled out that, after the acts of abuse, a perpetrator has already positively responded to the actual graces afforded him by God, feeling genuine repentance, performing penance and thus recovering sanctifying grace, the church can hardly be expected to be complacent and leave the offender to his own devices. Thus, the logic of grace suggests that Catholic restorative justice would aim to bring about the conditions under which the actual graces afforded by God to the offender with a view to his repentance may become efficacious, leading to the offender's recovery of sanctifying grace.

The Church's assistance, by way of restorative justice programs, in bringing about these conditions will be particularly necessary when, as in many of the clerical abuse cases, the sin was habitual. In these cases, it is more than possible that the sinner is of the obdurate (impenitent) ${ }^{110}$ variety - the kind whose heart has been 'darkened', whom God has given 'up to uncleanness', leading him to sin even more, doing 'things [that are] so sins themselves, that they [are] also the penalties of [initial] sins. ${ }^{111}$ Obdurate sinners are not granted actual grace in the form of repentance itself, but only lesser actual graces. ${ }^{112}$ These lesser spiritual gifts may eventually lead them to repent and re-attain justification, but this may prove a formidable task for them without the dedicated support of the Church.

In sum, the doctrine of grace suggests that Catholic restorative justice in cases of clerical sexual abuse should be directed at facilitating the process through which offenders can cooperate with the sufficient actual graces granted to obdurate sinners. Additionally or alternatively, the doctrine of grace makes it imperative for Catholic restorative justice to facilitate the perpetrators' performance of acts that will merit for them efficacious actual graces infallibly leading to their recovery of sanctifying grace. This is because, according to

\footnotetext{
${ }^{110}$ Pohle and Preuss Grace, Actual and Habitual pp 172-3.

${ }^{111}$ Augustin 'A Treatise on Nature and Grace' p 129.

112 Joyce The Catholic Doctrine of Grace pp 205-7.
} 
most theologians, sinners can obtain 'the dispositions necessary for justification' in the form of actual graces merited 'by good works ${ }^{113}$ - namely, morally good actions that are freely performed and ultimately done in the service of God (out of love for Him, or at least out of a desire to obey His commands, etc.). ${ }^{114}$

\subsection{Actual Grace and the Survivor of Abuse}

We have argued that the logic of the discourse of grace entails the risk that survivors of clerical child sexual abuse will not be the principal object of moral concern in Catholic restorative justice programs emphasising grace (unless their spiritual state requires urgent attention by reason of their having lapsed into unbelief). Furthermore, the doctrine of grace suggests that survivors may be involved in the rather demanding capacity of rehabilitators of their abusers, through the practice of forgiveness. This follows from what the doctrine of grace has to say about 'good works'. Through good works, the just may merit final perseverance as well as an increase in their sanctifying grace. ${ }^{115}$ The increase in grace is proportional to the will's commitment to the act, to the intensity of the charity that animates it, and to the difficulty of the act itself: forgiving a grave wrong deserves a greater reward than forgiving a light one. ${ }^{116}$ Significantly, however, the good works performed by the just

\footnotetext{
${ }^{113}$ Pohle and Preuss Grace, Actual and Habitual p 431.

${ }^{114}$ As above at p p 397, pp 410-17; Joyce The Catholic Doctrine of Grace pp 164-5, 173-4.

${ }^{115}$ Pohle and Preuss Grace, Actual and Habitual p 384-5, p 401, pp 432-4.

${ }^{116}$ Joyce The Catholic Doctrine of Grace pp 176-7. Grace is by definition an undeserved gift. Paul 'Titus' in United States Conference of Catholic Bishops The New American Bible, Revised Edition (NABRE) USCCB Publishing 2011 § 3.5 http://www.usccb.org/bible/titus/3; Pohle and Preuss Grace, Actual and Habitual p 131; Augustin 'A Treatise on the Grace of Christ' pp 122-3. Grace is not a requirement of justice, but issues from 'pure benevolence' and 'sheer love'. Pohle and Preuss Grace, Actual and Habitual p 6, 7; see also Augustin 'A Treatise on the Grace of Christ' p 225. Thus, it is the good work itself, rather than the human performing it,
} 
may also merit an increase in grace, final perseverance and conversion from mortal sin for others. ${ }^{117}$ Forgiving abuse (a mortal sin) qualifies precisely as the kind of highly meritorious good work by which the victim of abuse might deserve a considerable increase in sanctifying grace for him/herself and, more importantly, actual graces for the abuser - thereby facilitating his restoration to justification.

Forgiveness, however, is a highly contentious demand to make of victims, especially survivors of child sexual abuse. Forgiveness forms an important point of contention in feminist critiques of restorative justice. Although 'resolutely embedded in restorative justice processes', forgiveness has largely remained 'out of sight of examination' in mainstream and Christian restorative justice scholarship. ${ }^{118}$ When it is discussed, theorists remain divided about what forgiveness entails beyond 'a change in motivation toward the offender'. ${ }^{119}$ Hence Armour and Umbreit caution that, in general restorative justice proponents must clarify the role of forgiveness and provide guidance to practitioners to prevent a 'reductionism' that might distort the healing potential of any processes, especially among religious victims 'who have been told by their clergy that they must forgive in accordance with the tenets of their religion'. ${ }^{120}$ Victim respondents to the Irish Study 'had a lot to say' about forgiveness and apology. Some viewed apology as a primary function of the process of individual accountability by the offender, while others 'were concerned that the offender might be

that merits an increase in grace as its reward. Pohle and Preuss Grace, Actual and Habitual pp 38, 138;

Augustin 'A Treatise on the Grace of Christ' p 234; Joyce The Catholic Doctrine of Grace pp 161-4.

${ }^{117}$ Pohle and Preuss Grace, Actual and Habitual p 432, pp 433-4.

${ }^{118}$ Armour and Umbreit 'Victim Forgiveness' p 126. Emphasis added.

${ }^{119}$ As above at $\mathrm{p} 125$.

${ }^{120}$ As above at pp $125-6$. 
seeking to manipulate the victim into forgiving them for selfish rather than genuine reasons'. ${ }^{121}$

It cannot be ruled out that survivors may experience a call for forgiveness in empowering ways, particularly as it has an intriguing potential for reversing - within the domain of spiritual relations - the power dynamic between victim and abuser, as hoped by Hudson and others. ${ }^{122}$ Indeed, the more obdurate the sinner, the more he will be likely to need, according to the logic of grace, the victim's good works on his behalf. At the same time, any call for forgiveness may all too easily turn into a psychologically burdensome responsibility - an emotionally exploitative imperative, even - to forgive. This seems particularly likely, given the implication following from the discourse of grace that any internal appeal to forgive presenting itself to the victim's mind must be an actual grace coming from God and demanding the cooperation of the survivor's will.

The concerns voiced by Stubbs about the use or abuse of emotion in restorative practices are highly pertinent in this context, and appear to mirror the more strident arguments made for restorative justice in the context of spirituality and faith. ${ }^{123}$ Some Catholic restorative justice mediators do indeed describe their work in terms of invoking emotions from church representatives and complainants. The power of the mediation is associated with the 'emotional connection and energy that flows from the interaction between the giver and the receiver. It is the sharing of this emotional experience that gives the apology its healing force'. ${ }^{124}$ To avoid the 'reductionism' forewarned by Armour and

\footnotetext{
${ }^{121}$ Keenan Sexual Trauma and Abuse p 178.

${ }^{122}$ See note 9.

${ }^{123}$ See note 26 .

${ }^{124}$ Rooney Submission by Greg Rooney to the Royal Commission p 111. Rooney Greg and Ross Margaret 'Mediating between Victims of Sexual Abuse and Religious Institutions' (2007) 18 Australasian Dispute Resolution Journal 10 p 15.
} 
Umbreit, church-appointed mediators must be aware of their own emotional desires for outcomes, and that they are 'not an empty vessel'; ${ }^{125}$ instead, they bring with them personal spiritual and ideological 'prejudices, beliefs and emotional reactions', ${ }^{126}$ particularly those favouring grace as salvation for the offender as the foremost priority of mediation.

\subsection{Conclusions}

Appeals to the healing potential of 'grace' and 'forgiveness' are central to much restorative justice scholarship. This literature, however, does not adequately explain the meaning or use of 'grace' which, we have argued, has a range of precise and technical meanings within Catholic thought. It is only by clarifying and interrogating these meanings that a fuller understanding can be gained of what is envisioned by Catholic restorative justice, especially in the context of clerical child sexual abuse where the church has internationally moved into the terrain of alternative dispute resolution through the implementation of in-house mediation schemes. In restorative justice scholarship, 'forgiveness' occupies in general a confused or contested position, the emotionally exploitative risks of which feminist criminologists have highlighted in the context of gender-based offences such as sexual abuse.

The trite use of complex concepts such as 'grace' by advocates of restorative justice lends itself to manipulation in ways that are detrimental to victims of sexual crime. These problems are compounded, we have argued, by the fact that the unreflective use of these concepts in orthodox scholarship has the effect of ratifying and lending authority to religious understandings of 'grace' that are odds with the purportedly victim-centred ethos of restorative justice. The Catholic doctrine of grace entails that in the context of Catholic restorative justice the goal of restoring justice to victims who have not lapsed into unbelief

\footnotetext{
${ }^{125}$ Rooney Submission by Greg Rooney to the Royal Commission p 113.

${ }^{126}$ Rooney and Ross 'Mediating between Victims of Sexual Abuse and Religious Institutions' p 13.
} 
would take second place to the goal of restoring justification to the offender. Hence Catholic advocacy of restorative justice in cases of clerical child sexual abuse warrants especially careful scrutiny in light of well-established feminist critiques of restorative justice in the context of sexual crime. 